\title{
Aizoago, a new genus, and two new species of smut fungi (Ustilaginales) on Tetragonia (Aizoaceae) in Australia
}

\section{Kálmán Vánky ${ }^{1 *} \&$ Roger G. Shivas ${ }^{2}$}

\author{
${ }^{1}$ Herbarium Ustilaginales Vánky (H.U.V.), Gabriel-Biel-Str. 5, D-72076 Tübingen, Germany \\ ${ }^{2}$ Plant Pathology Herbarium, Department of Agriculture, Fisheries and Forestry, Ecosciences Precinct, \\ Dutton Park, Qld 4102, Australia
}

Received 5 December 2012 / Accepted 18 December 2012 / Published 11 January 2013

Vánky, K. \& Shivas, R.G. 2013. Aizoago, a new genus, and two new species of smut fungi (Ustilaginales) on Tetragonia (Aizoaceae) in Australia. - Mycobiota 1: 1-7. doi: 10.12664/mycobiota.2013.01.01

\begin{abstract}
A new genus of smut fungi, Aizoago, is described and illustrated, with two new species, $A$. tetragoniae on Tetragonia diptera and $A$. tetragonioides on $T$. tetragonioides (Aizoaceae), from Australia.
\end{abstract}

Key words: Aizoaceae, Aizoago tetragoniae, Aizoago tetragonioides, Australian biodiversity, taxonomy, Tetragonia, smut fungi

\section{Introduction}

An interesting parasitic fungus was collected in 1971 on Tetragonia diptera (Aizoaceae), in Western Australia, by H.L. Harvey, and deposited in Herb. Kew (IMI 162 907) as Melanopsichium sp. Two similar collections on Tetragonia tetragonioides were made by D. Parsons in 1983, in New South Wales, Australia (DAR 33 889a, DAR 33 901). These three specimens were studied, described in detail and illustrated by Walker (2007), who, at first, suspected that the presence of hyaline, cylindrical, obclavate or Y-shaped conidia between the spores, indicated that the fungus was a Conidiosporomyces (Tilletiaceae). This is unlikely as species of Conidiosporomyces are only known on Poaceae. Inspired by the detailed paper of Walker (2007), the authors decided to study this enigmatic fungus on Tetragonia.

\section{Materials and methods}

Spore characteristics and spore formation were studied using dried herbarium specimens, kept in BRIP, DAR, IMI and H.U.V. For light microscopy (LM) spores were suspended

*Corresponding author: e-mail: vanky.k@cityinfonetz.de 
Fig. 1. Sori of Aizoago tetragoniae on the pedicel and deformed fruit of Tetragonia diptera (type). Habit. Bar $=1 \mathrm{~cm}$

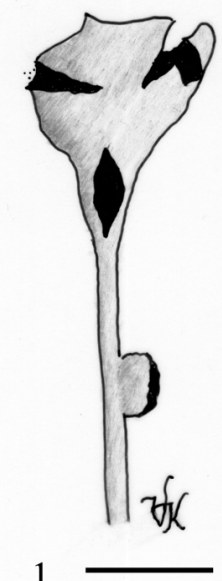

in a small droplet of lactophenol, or lactophenol with cotton blue, covered with a cover glass, gently heated to boiling point to rehydrate the spores and expel air bubbles from the preparation, and studied at $1000 \times$ magnification. For scanning electron microscopy (SEM), spores were placed on double-sided adhesive tape, mounted on a specimen stub, sputter-coated with gold, ca $20 \mathrm{~nm}$, and examined in a SEM at $10 \mathrm{kV}$.

\section{Results and discussion}

Based on the characters described below, the curious parasitic microfungus on Tetragonia diptera and T. tetragonioides is a smut fungus. On the two host plant species there are two, morphologically well characterised species, belonging to an unknown genus.

The sori are bullate, covered by host tissue, and filled with a blackish brown, semiagglutinated mass of spores. Mature spores are solitary, pigmented, ornamented and with a well-developed, pale coloured or subhyaline sheath. The spores are produced in septate, sporogenous hyphae. This type of spore formation occurs in many smut fungi, e.g. Farysia, Sphacelotheca hydropiperis, Ustilago cynodontis, Zundeliomyces polygoni. Spore germination is not known. Walker (2007: 52, Fig. 2c) also described hyaline, straight or Y-shaped conidia, as well as small, one- or two-celled, smooth, dark brown spores in some specimens, which we consider belong to saprobic fungi together with the culture obtained by Walker (2007: 53). This smut fungus does not fit into any known genus (comp. Vánky 2002, 2011). It is described as follows.

Aizoago Vánky, gen. nov.

MrcoBank MB 802766

Sori in partibus vegetativis et fructibus plantarum familiae Aizoaceae, bullati, massa sporarum atrearum, semiagglutinatarum completi. Neque columella nec cellulae steriles praesentes. Sporae solitariae, pigmentatae (flavobrunneae, non violaceo-vel rubro-tinctae), ornamentatae et obductae per vaginam crassam. Typus generis: A. tetragoniae. 
Sori on vegetative parts and fruits of plants in Aizoaceae, bullate, filled with a dark, semiagglutinated mass of spores. Columella and sterile cells absent. Spores solitary, pigmented (yellowish brown, no violet or reddish tint), ornamented and covered by a thick sheath.

Type of the genus: $A$. tetragoniae.

Etymology: Aizoa-from the host plant family Aizoaceae, and -ago from Ustilago.

Aizoago tetragoniae Vánky \& R.G. Shivas, sp. nov.

MycoBank MB 802769

Typus in matrice Tetragonia diptera F. Muell., Australia, Western Australia, Shark Bay, 1971, leg. H.L. Harwey (holotypus, IMI 162907; isotypi, DAR 59 828, H.U.V. 21961 !).

Sori in caulibus et fructibus tumores bullatos usque $1 \mathrm{~cm}$ diametro producentes, primo telis nutricientibus coopertos, maturitate disruptos, ostendentes massam atro-rufobrunneam, semiagglutinatam sporarum. Columella nulla, neque cellulae steriles. Sporae globosae, subglobosae, ellipsoidales usque parum irregulares, 22,5-30 × 24-36 $\mu \mathrm{m}$, includens vagina. flavidobrunneae cum equaliter 0,5-0,8 $\mu \mathrm{m}$ crasso, pariete indistincte, complete vel plerumque incomplete reticulato et etiam saepe disperse verruculoso. Muri in superficie sporae tenues, acuti,

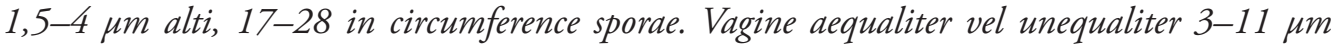
crassae, pallide flavidobrunneae, e strato parum atriore latiore, in quo muri penetrantes, et stratis 1-3 externis pallidioribus compositae. Sporae in hyphis septatis sporogeneis formatae.

Sori (Fig. 1) form in bullate swellings up to $1 \mathrm{~cm}$ in diam on the stems and fruits, first covered by host tissue that ruptures at maturity, exposing the dark reddish brown, semiagglutinated mass of spores. Columella and sterile cells absent. Spores (Figs 2, 3, 7) globose, subglobose, ellipsoidal to slightly irregular, 22.5-30 × 24-36 $\mu \mathrm{m}$ (including the sheath), yellowish brown; wall $0.5-0.8 \mu \mathrm{m}$ thick, even, completely or more often incompletely reticulate, often sparsely verruculose. Muri on the spore circumference thin, acute, 1.5-4 $\mu \mathrm{m}$ high, 17-28 on the spore circumference. The sheaths are evenly or unevenly 3-11 $\mu \mathrm{m}$ thick, pale yellowish brown, composed of a slightly darker inner layer, into which the muri penetrate, and 1-3 paler outer layers. Spore formation (Figs 4-6) in septate sporogenous hyphae, in rows or rarely in groups. Immature spores globoid, rounded subpolyhedrally irregular, rarely elongate or lacrymiform, at beginning lacking sheath, having only a thin, hyaline spore wall that becomes pigmented and finally ornamented with a subhyaline sheath.

On Aizoaceae: Tetragonia diptera.

Geographic distribution: Australia. Known only from the type locality.

Aizoago tetragonioides Vánky \& R.G. Shivas, sp. nov.

MycoBank MB 802772

Typus in matrice Tetragonia tetragonioides (Pallas) Kuntze; Australia, NSW, Moree, 28.VII.1983, leg. D. Parsons (holotypus, DAR 33 869a); paratypus ibidem, 19.IX.1983, D. Parsons (DAR 33 901, H.U.V. 21984 - a slide).

Aizoago tetragonioides a specie Aizoago tetragoniae distinctus sporis pluribus, minoribus, reticulo magis evoluto et vagina tenuiore. 

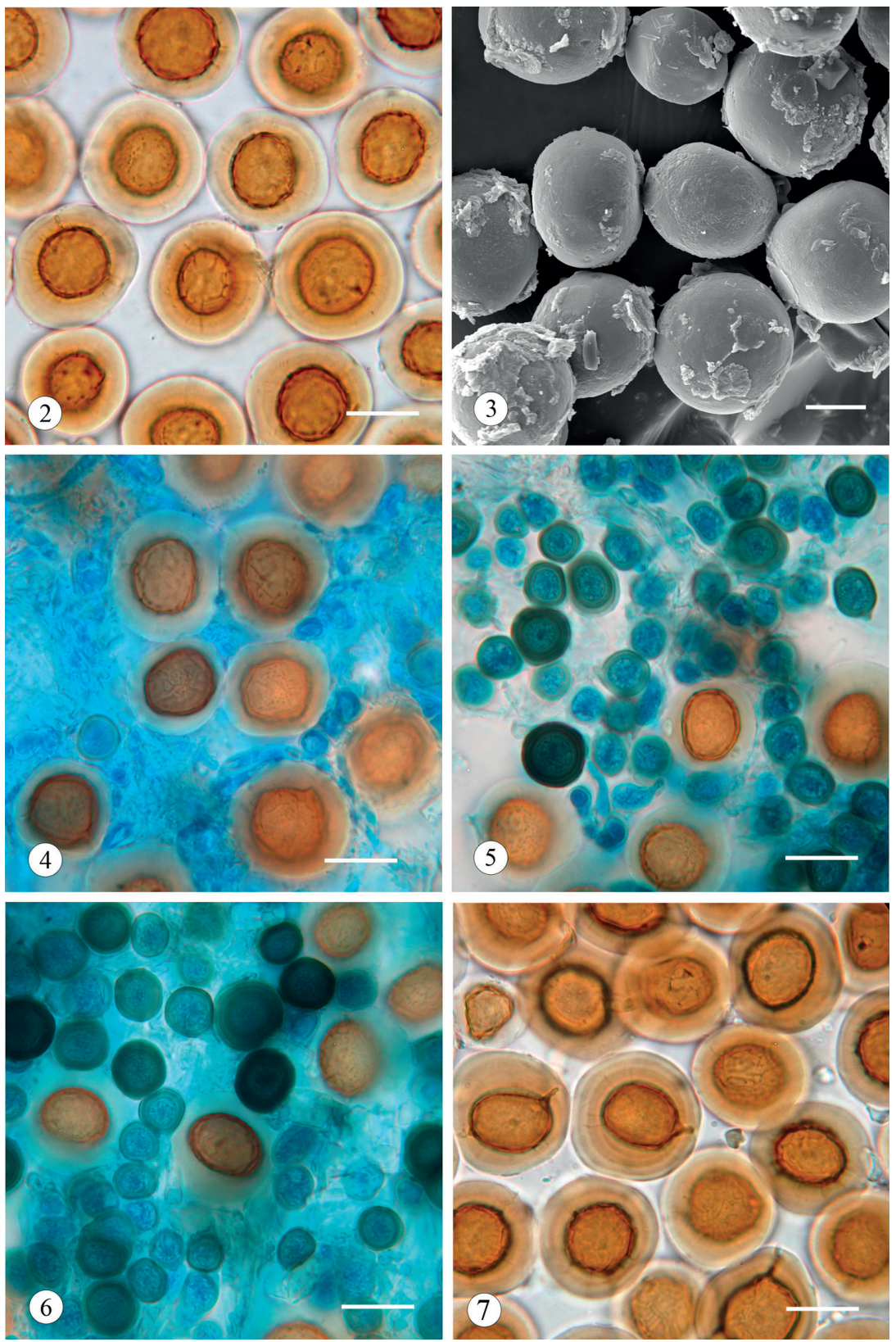

Figs 2, 3. Mature spores of Aizoago tetragoniae on Tetragonia diptera in LM and in SEM (type). Bars $=10 \mu \mathrm{m}$. Figs 4-6. Spore formation of Aizoago tetragoniae on Tetragonia diptera, stained with cotton blue in lactophenol, showing the septate sporogenous hyphae with spores of different developmental stages, in LM (type). Bars $=10 \mu \mathrm{m}$. Fig. 7. Spores of Aizoago tetragoniae on Tetragonia diptera in LM, optical median view, showing the structure of the sheath and in some spores one or two, oppositedly situated, narrow channels (type). Bar $=10 \mu \mathrm{m}$ 
Aizoago tetragonioides differs from Aizoago tetragoniae in having spores with several, smaller, more complete reticula, and thinner sheathes.

Sori in the fruits of Tetragonia tetragonioides (Figs 8, 9) form bullate swellings filled by dark reddish brown, semiagglutinated spore masses. Spores (Figs 10-13) subglobose, usually broadly ellipsoidal, rarely slightly irregular, pyriform or elongated, (15-)16-24 × 20-30(-34) $\mu \mathrm{m}$ (including the sheath), pale to medium dark yellowish brown; wall several layered, 4-7 $\mu \mathrm{m}$ thick, composed of a hyaline, evenly c. $0.5 \mu \mathrm{m}$ thick endospore, a dark yellowish brown, ornamented, evenly $1-1.5 \mu \mathrm{m}$ thick exospore (without ornamentation), and a paler sheath of even or uneven thickness. Exospore delicately, irregulaly reticulate, meshes complete or incomplete, of various shape and size, muri thin, in median view appearing as fine, narrow, radial, 1.5-3 $\mu \mathrm{m}$ long spines, 28-36 on the spore circumference, completely covered by the sheath. Sheath 1.5-4 $\mu \mathrm{m}$ thick, one or two layered; one-layered sheath pale yellowish brown; two-layered sheath with an outermost, thin, paler layer. Spores ocassionally provided with one or two, oppositely situated, short, hyaline appendages, pyriform or lemon-shaped, with a narrow pore penetrating the spore wall.

On Aizoaceae: Tetragonia tetragonioides.

Geographic distribution: Australia. Known only from the type locality.

\section{Key to the species of Aizoago on Tetragonia}

1 Spores 24-36 $\mu \mathrm{m}$ long, incompletely reticulate; sheath 3-11 $\mu \mathrm{m}$ thick; muri $1.5-4 \mu \mathrm{m}$ high, 17-28 on the spore circumference; on T. diptera . . . . . . . A. tetragoniae

$1 *$ Spores 20-30(-34) $\mu \mathrm{m}$ long, completely reticulate; sheath 1.5-4 $\mu \mathrm{m}$ thick; muri 1.5-3 $\mu \mathrm{m}$ high, 28-36 on the spore circumference; on T. tetragonioides . . A. tetragonioides

The Aizoaceae contains about 127 genera and 1860 species (Mabberley 2008). Only one smut fungus is known on the Aizoaceae: Talbotiomyces calosporus (P.H.B. Talbot) Vánky, R. Bauer \& Begerow on Trianthema pentandra L., from South Africa (Vánky et al. 2007). At the same time, other families of the order Caryophyllales, such as the Caryophyllaceae and Polygonaceae, are hosts to a large number of smut fungi. The Amaranthaceae (5 species of Thecaphora) and Droseraceae (Yelsemia droserae R.G. Shivas, Vánky \& P. Athipunyakom) also have smuts, but not the Cactaceae, which has about 1200 species.

Acknowledgements. The authors are grateful to Dr. Sándor Tóth (Gödöllö, Hungary) for preparing the Latin diagnoses, and to the keeper of DAR for loan of specimens. The technical assistance of Mrs. Christine Vánky (HUV, Tübingen, Germany) with the illustrations, and that of Mrs Monika Weinert (University, Tübingen, Germany) with preparation of the SEM picture of the spores, is gratefully acknowledged. 

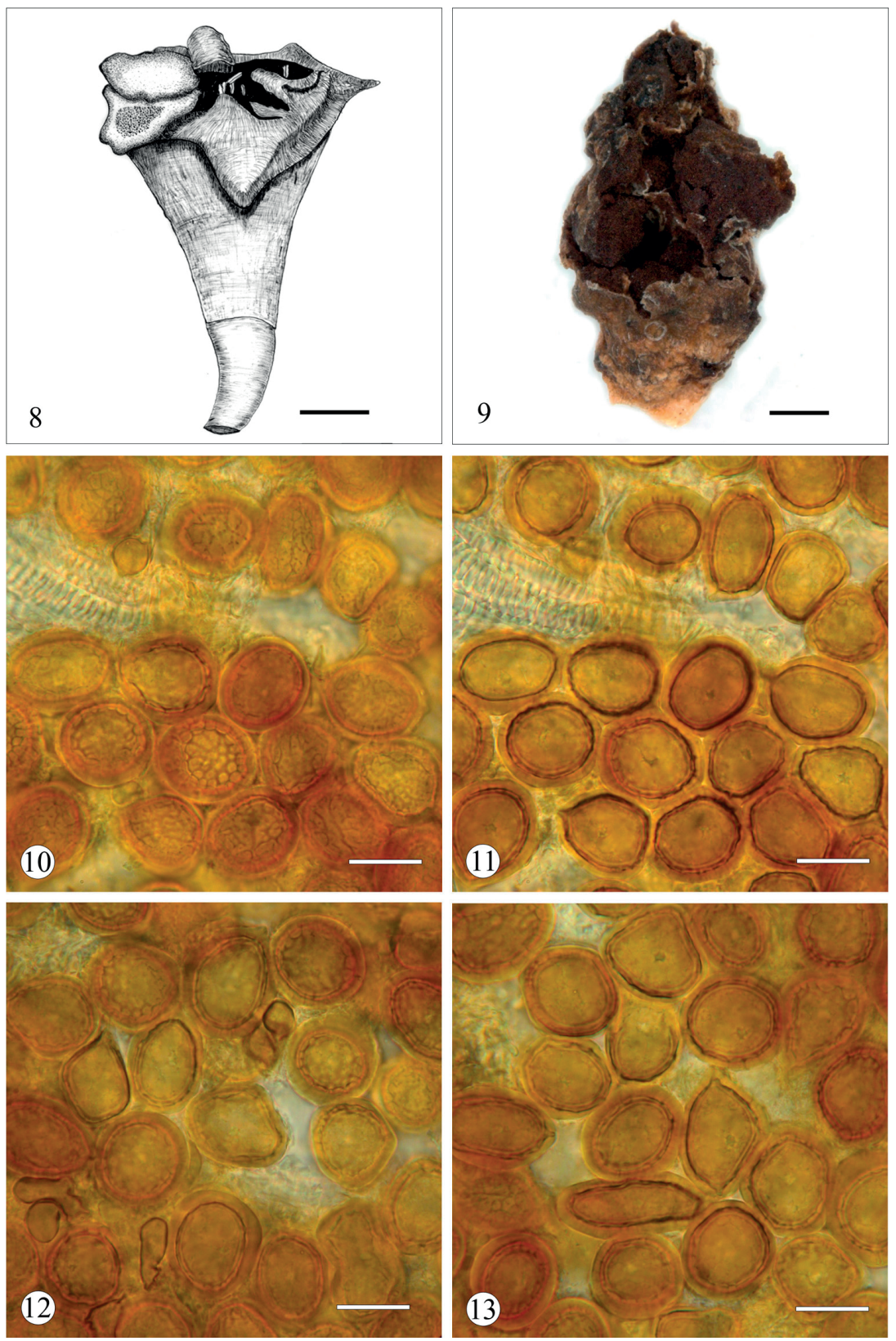

Fig. 8. Sori of Aizoago tetragonioides forming pustules on a fruit of Tetragonia tetragonioides (type, after Walker 2007: 52, Fig. 1). Habit. Bar $=2 \mathrm{~mm}$. Fig. 9. An opened sorus of Aizoago tetragonioides with the dark brown, semiagglutinated mass of spores on Tetragonia tetragonioides (type). Bar $=1 \mathrm{~mm}$. Figs 10-13. Spores of Aizoago tetragonioides on Tetragonia tetragonioides in LM (type). Bar $=10 \mu \mathrm{m}$. In Fig. 12, conidia of saprophytic fungi between the spores of A. tetragonioides are present. In Fig. 13, an elongated spore and one with two, oppositely situated, short, hyaline appendages can be seen. 


\section{References}

Mabberley, D.J. 2008. Mabberley's plant-book. Cambridge University Press, UK.

Vánky, K. 2002. Illustrated genera of smut fungi. 2nd edn. APS Press, St. Paul, Minnesota, USA.

Vánky, K. 2011('2012'). Smut fungi of the world. APS Press, St. Paul, Minnesota, USA.

Vánky, K., Shivas, R.G. \& Athipunyakom, P. 2006. New smut fungi (Ustilaginomycetes) from Thailand. Mycologia Balcanica 3: 107-118.

Vánky, K., Bauer, R. \& Begerow, D. 2007. Talbotiomyces, a new genus for Entorrhiza calospora (Basidiomycota). - Mycologia Balcanica 4: 11-14.

Walker, J. 2007. An undetermined fungus infecting fruits of Tetragonia (Aizoaceae) in Australia. - Australasian Mycologist 26: 51-54. 
